\title{
The inevitability of molecular methods for drinking water analysis
}

\author{
E. S. Al Saleh, A. Eissa, H. Drobiova, Z. Taqi \& C. Obuekwe \\ Microbiology Program, Department of Biological Sciences, \\ Faculty of Science, Kuwait University, Kuwait
}

\begin{abstract}
Drinking water regulations focus on the absence of indicator microorganisms in drinking water supplied to the end consumers to avoid the spread of potential diseases to members of the community. However, low counts of total heterotrophic bacteria are permissible. In general, total heterotrophic plate counts (HPC) may be used to represent the general hygiene of water where high HPC could indicate the presence of pathogenic bacteria, e.g. coliforms. Almost all of the standard methods for testing drinking water samples are culture-dependent methods that only detect microorganisms capable of utilizing standard microbiological culture media. However, the presence of viable but not culturable (unculturable) microorganisms (VBNC) makes it extremely important to employ techniques capable of detecting this fraction of water-borne microorganisms. Thus, the aim of the current study was to compare the outcome of applying traditional and molecular techniques for drinking water analysis. Results demonstrated the presence of VBNC bacteria such as Salmonella enterica, Corynebacterium glutamicum, Brachybacterium faecium, Clostridium phytofermentans, Enterobacter sp., Beutenbergia cavernae, Saccharomonospora viridis, Bacillus subtilis, Fervidobacterium nodosum in some water samples, which were not detected by traditional techniques. This suggested that, molecular techniques are inevitable and more reliable than traditional methods. Keywords: drinking water analysis, membrane filtration, $16 S \mathrm{rRNA}$.
\end{abstract}

\section{Introduction}

The requirement for potable water in modern societies is continuously rising with the increase in the size of populations and the standards of living. 
Additionally, the low average rainfall and the insufficiency of fresh water resources increased the magnitude of meeting the demand of potable water. Thus, different technologies such as desalination and filtration technologies were employed to meet such increase in the demand of potable water. Generally, provision and consumption of potable water is associated with numerous microbiological problems which require the incessant monitoring of drinking water for total heterotrophic bacteria (Gerba [1]) and coliforms (Gerba [1]; Prescott et al. [2]). Coliforms such as E. coli were used as bacterial indicators of microbial water quality because they present in high numbers in faeces of humans and warm-blooded animals (Madigan et al. [3]). Practically, presence of $E$. coli as an indicator bacterium is based on the fact that it is not habitually found in drinking water niches and it can be easily detected biochemically (Gerba [1]; Madigan et al. [3]). Another non-coliform bacteria used as an indicator of faecal contamination and microbial water quality are the faecal streptococci (Gerba [1]; Levesque et al. [4]). However, since faecal streptococci hardly survive in water for a long time, usually they are not used as indicators for microbial contamination of potable water (Ashbolt et al. [5]).

Methods that are used to detect total or fecal coliforms are mainly enumeration methods based on lactose fermentation (Cappucino and Sherman [6]). Three methods are commonly used to identify coliforms in water. The most probable number (MPN), membrane filter (MF), and the presence-absence (PA) tests (Gerba [1]). These methods require cultivation of bacteria, hence they need 24-48 hours to complete which makes it impossible to take sanitary measures instantly after occurrence of fecal pollution (George et al. [7]). In addition, fecal bacteria loose rapidly their ability to form visible colonies on specific media, while preserving their potential for virulence. Therefore, it is apparent that standard methods could give false negative results (George et al. [7]). Thus, with the advancement of science, molecular techniques for instance PCR are applied and appeared to be more sensitive, quicker, multiple targets can be detected at once and enabled the detection of fastidious, health-significant microorganisms that replicate poorly or not at all on standard microbiological growth media. (Bej et al. [8]; Tsen et al. [9]; Venkateswaran et al. [10]; Yamamoto and Harayama [11]). This cuts down time, labor, and overall cost of the detection process (Mukhopadhyay and Mukhopadhyay [12]).

Furthermore, molecular quantification techniques such as RT-PCR are also employed in water screening research (Fey et al. [13]; Guy et al. [14]; Layton et al. [15]). Therefore, the objective of the current study was to compare the potentials of the traditional and molecular methods to monitor bacterial contamination of drinking water samples in residential areas in Kuwait city.

\section{Materials and methods}

\subsection{Sampling and collection}

Drinking water samples (2L in triplicates) were collected from households and public outlets (co-ops, schools, colleges, malls, parks, and mosques) of 14 
residential areas of Kuwait city. Samples were collected in sterile containers, kept at $4^{\circ} \mathrm{C}$ and transported immediately to the lab for immediate analyses.

\subsection{Enumeration and identification of bacteria}

Presence of Gram-negative bacteria was determined using MacConkey (MAC) agar plates on which membranes of filtered water samples were placed and grown colonies were counted. Isolated bacteria were identified by sequencing of 16S rDNA gene. For this purpose the method of Kuske et al. [16] was followed. The 16S rDNA sequences obtained were run against the data bases using the basic alignment search tool (BLAST). For the identification of viable but not culturable bacteria, water sample (1L) was centrifuged (5000 rpm for $15 \mathrm{~min}$ at $5^{\circ} \mathrm{C}$ ) and the pellet was used for the purification of genomic DNA and used for the construction of small-subunit rDNA libraries from 16S rDNA sequences amplified from extracted DNA using $27 \mathrm{~F}$ and 1492R primers as mentioned previously (Kuske et al. [16]). Sequencing of positive clones was carried by using M13 vector-specific primers. Sequence analysis and alignments was conducted as mentioned previously.

\section{Results and discussion}

The current study investigated the microbiological and molecular analyses of drinking water samples collected from residential areas in Kuwait city. The analyses of water samples showed the presence of Gram-negative bacteria in 10 out of the 14 areas of Kuwait city (Table 1).

Following standard drinking water monitoring procedures, only three out of fourteen areas $(21 \%)$ showed significant culturable bacterial contamination in areas 12, 13 and 14. The construction of the 16S rDNA libraries for the detection of unculturable bacteria in water samples showed the presence of highly diverse bacterial communities of Gram-negative and Gram-positive bacteria (Table 2).

The detected Gram-negative bacteria were most probably unculturable since they were not detected on culture media used. On the other hand, the Grampositive bacteria detected by PCR could be culturable because the selective media used, inhibited the growth of Gram-positive bacteria. Nonetheless, some of the Gram-positive bacteria detected such as Clostridium are of medical concern. Apparently, the culturable and the unculturable bacteria detected in the current study survived the prevailed experimental and environmental conditions and the levels of chlorination used in Kuwait. Moreover, the unculturable Gramnegative bacteria detected such as Acinetobacter, Citrobacter, Pseudomonas, Salmonella and Campylobacter (Table 2) are considered serious human health hazards. Additionally, the phylogenetic analysis of three selected bacteria demonstrated presence of highly diverse unculturable bacterial communities (Figures 1-2) possibly harboring different metabolic and pathogenic potentials. 
Table 1: Counts of culturable and unculturable bacteria in drinking water samples collected from Kuwait city.

\begin{tabular}{cccc}
\hline \hline \multirow{2}{*}{ Sampling area } & \multicolumn{2}{c}{ Culturable Gram -ve bacteria } & \multicolumn{2}{c}{ Unculturable bacteria } \\
\cline { 2 - 4 } & CFU/2L & Gram-ve & Gram+ve \\
\hline \hline 1 & 0 & 19 & 15 \\
2 & 6 & 7 & 6 \\
3 & 6 & 9 & 4 \\
4 & 7 & 3 & 8 \\
5 & 1 & 9 & 4 \\
6 & 2 & 6 & 6 \\
7 & 12 & 21 & 13 \\
8 & 0 & 5 & 5 \\
9 & 0 & 6 & 4 \\
10 & 0 & 8 & 6 \\
11 & 1 & 5 & 6 \\
12 & 32 & 6 & 9 \\
13 & 49 & 6 & 3 \\
14 & 41 & 9 & 5 \\
\hline \hline
\end{tabular}

Table 2: $\quad$ Identities of unculturable gram-negative and gram-positive bacteria detected in drinking water samples collected from Kuwait city.

\begin{tabular}{|c|c|c|}
\hline Area & Gram-positive bacteria & Gram-negative bacteria \\
\hline 1 & $\begin{array}{c}\text { Bacillus halodurans, } \text { C. difficile, } \\
\text { Corynebacterium glutamicum, Geobacter } \\
\text { bemidjiensis, S. mitis, T. thermophilus }\end{array}$ & $\begin{array}{l}\text { Acinetobacter baumannii, Azoarcus } \\
\text { aromaticum, Caulobacter sp., } \\
\text { Gluconobacter oxydans, } V \text {. fischeri }\end{array}$ \\
\hline 2 & $\begin{array}{l}\text { Mycobacterium sp., Clostridium difficile, } \\
\text { Streptosporangium roseum }\end{array}$ & $\begin{array}{c}\text { Salmonella enterica, Megamonas } \\
\text { hypermegale, Buchnera aphidicola, } \\
\text { Leptotrichia buccalis }\end{array}$ \\
\hline 3 & $\begin{array}{l}\text { Streptomyces ambofaciens, Rubrobacter } \\
\text { xylanophilus, Clostridium sp., subtilis }\end{array}$ & $\begin{array}{c}\text { Pseudomonas fluorescens, } \\
\text { Acidovorax citrulli, Yersinia } \\
\text { enterocolitica }\end{array}$ \\
\hline 4 & $\begin{array}{c}\text { Clostridium sp., Conexibacter woesei, } \\
\text { Mycobacterium sp., Thermus } \\
\text { thermophilus }\end{array}$ & $\begin{array}{c}\text { Buchnera aphidicola, Chitinophaga } \\
\text { pinensis }\end{array}$ \\
\hline 5 & $\begin{array}{l}\text { Clostridium acetobutylicum, } \\
\text { Desulfatibacillum alkenivorans, } \\
\text { Streptosporangium roseum }\end{array}$ & $\begin{array}{c}\text { Buchnera aphidicola, } \\
\text { Campylobacter lari, Citrobacter } \\
\text { rodentium, P. aeruginosa, Ralstonia } \\
\text { eutropha }\end{array}$ \\
\hline 6 & $\begin{array}{c}\text { Bacillus cereus, Bacillus subtilis, } \\
\text { Clostridium phytofermentans, } \\
\text { Geobacillus sp., Thermus thermophilus }\end{array}$ & $\begin{array}{l}\text { Flavobacterium psychrophilum, } \\
\text { Proteus mirabilis, } P \text {. putida }\end{array}$ \\
\hline 7 & $\begin{array}{c}\text { Bacillus cereus, Clostridium difficile, } \\
\text { Geobacter bemidjiensis, Mycobacterium } \\
\text { sp., Streptomyces nanchangensis, } \\
\text { Thermus thermophilus }\end{array}$ & $\begin{array}{c}\text { Bacteroides fragilis, Caulobacter } \\
\text { sp., Flavobacterium johnsoniae, } \\
\text { Nitrosospira multiformis, } \\
\text { Thermocrinis albus }\end{array}$ \\
\hline 8 & $\begin{array}{c}\text { Clostridium sp., Mycobacterium sp., } \\
\text { Ruminococcus torques, Thermus } \\
\text { thermophilus }\end{array}$ & $\begin{array}{c}\text { Buchnera aphidicola, Rickettsia } \\
\text { bellii, Sinorhizobium meliloti, } \\
\text { Saccharomonospora viridis }\end{array}$ \\
\hline
\end{tabular}


Table 2: $\quad$ Continued.

\begin{tabular}{|c|c|c|}
\hline Area & Gram-positive bacteria & Gram-negative bacteria \\
\hline 9 & $\begin{array}{c}\text { Clostridium sp., Ruminococcus torques, } \\
\text { Streptomyces griseus }\end{array}$ & $\begin{array}{l}\text { Acinetobacter baumannii, } \\
\text { Bradyrhizobium sp., Shewanella sp., } \\
\text { Fervidobacterium nodosum }\end{array}$ \\
\hline 10 & $\begin{array}{c}\text { Brachybacterium faecium, Clostridium } \\
\text { perfringens, Staphylococcus } \\
\text { saprophyticus }\end{array}$ & $\begin{array}{c}\text { Brachyspira hyodysenteriae, } B . \\
\text { aphidicola, Campylobacter lari, E. } \\
\text { coli, Xenorhabdus bovienii }\end{array}$ \\
\hline 11 & $\begin{array}{l}\text { Bacillus sp., Bacillus, Clostridium } \\
\text { perfringens, Streptococcus equi, }\end{array}$ & $\begin{array}{c}\text { C. concisus, Dickeya zeae, } F \text {. } \\
\text { psychrophilum, Sebaldella termitidis }\end{array}$ \\
\hline 12 & $\begin{array}{l}\text { Mycobacterium sp., Nocardia farcinica, } S \text {. } \\
\text { epidermidis, Streptomyces ambofaciens }\end{array}$ & $\begin{array}{l}\text { Agrobacterium vitis, B. japonicum, } \\
\text { R. palustris, Enterobacter sp. }\end{array}$ \\
\hline 13 & $\begin{array}{l}\text { Propionibacterium freudenreichii, } \\
\text { Thermus thermophilus, }\end{array}$ & $\begin{array}{l}\text { B. japonicum, Leptotrichia buccalis, } \\
\text { Methylobacterium sp., R. capsulatus }\end{array}$ \\
\hline 14 & $\begin{array}{c}\text { Mycobacterium sp., Rhodococcus } \\
\text { erythropolis, } \\
\text { Beutenbergia cavernae, }\end{array}$ & $\begin{array}{c}\text { Buchnera aphidicola, Nitrobacter } \\
\text { hamburgensis, Shewanella } \\
\text { halifaxensis, Brachybacterium } \\
\text { faecium }\end{array}$ \\
\hline
\end{tabular}

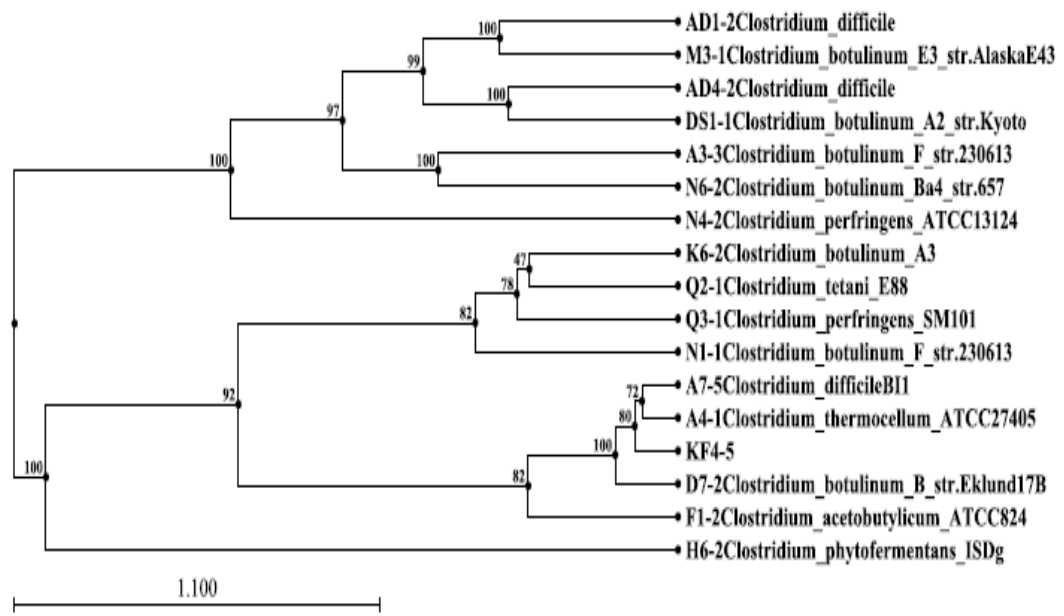

Figure 1: Dendrogram constructed by UPGMA cluster analysis of similarity coefficients derived from RFLP analysis of $16 \mathrm{~S}$ rDNA of selected unculturable Clostridium strains detected in drinking water samples obtained with BstUI. The levels of linkage representing the Dice correlation/UPGMA are expressed as percentages and shown at each node. 


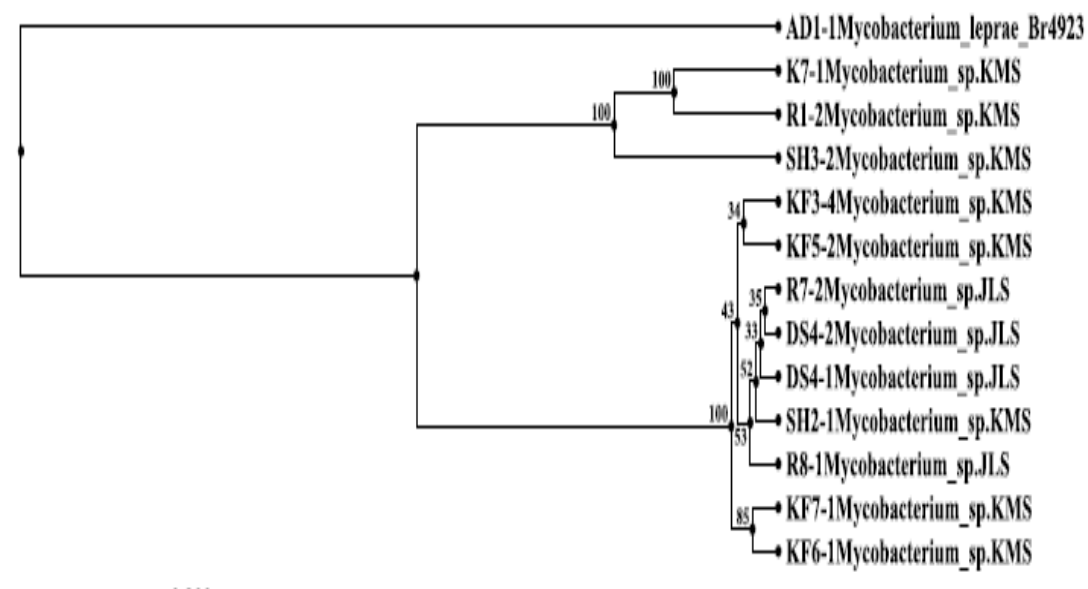

0.900

Figure 2: Dendrogram constructed by UPGMA cluster analysis of similarity coefficients derived from RFLP analysis of $16 \mathrm{~S}$ rDNA of selected unculturable Mycobacterium strains detected in drinking water samples obtained with Bst UI. The levels of linkage representing the Dice correlation/UPGMA are expressed as percentages and shown at each node.

\section{Conclusions}

The molecular approaches offered higher sensitive and reliable methods for the detection of culturable and unculturable bacteria and probably other microorganisms. Thus, it is recommended that molecular methods should be employed for the monitoring of drinking water samples. Moreover, drinking water monitoring authorities must trace the source of bacterial contamination to prevent and avoid potential spread of waterborne diseases between members of the community.

\section{Acknowledgements}

This project was funded by the Research Administration (SL03/07) - Kuwait University. The sequencing service of the Biotechnology Center (BTC) is greatly appreciated. 


\section{References}

[1] Gerba, C.P. Indicator microorganisms. In: Environmental microbiology (Raina M. Maier, Ian L. Pepper, Charles P. Gerba) USA, 2000.

[2] Prescott, L.M., Harley, J.P. and Klein, D.A. Microbiology, 3rd edition. Wm. C. Brown Publishers, USA, 1996.

[3] Madigan, M. T., Martinko, J. M. and Parker, J. Brock biology of microorganisms. Pearson Education, Inc. NJ, USA, 2003.

[4] Levesque, B., Simard, P., Gauvin, D., Gingras, S., Dewailly, E. and Letarte, R. Comparison of the microbiological quality of water coolers and that of municipal water systems. Appl Environ Microbiol 60(4), pp. 1174-8, 1994.

[5] Ashbolt, N.J., Grabow, W.O.K. and Snozzi, M. Indicators of microbial water quality. In: Water quality: guidelines, standards and health (Lorna Fewtrell, Jamie Bartram) UK, 2001.

[6] Cappucino, J.G. and Sherman, N. Microbiology: a laboratory manual, $6^{\text {th }}$ edition. Benjamin Cumings, USA, 2002.

[7] George, I., Petit, M. and Servais, P. Use of enzymatic methods for rapid enumeration of coliforms in freshwaters. J Appl Microbiol 88, pp. 404-413, 2000.

[8] Bej, A.K., Mahbubani, M.H., DiCesare, J.L. and Atlas, R.M. PCR-Gene probe detection of microorganisms using filter-concentrated samples. Appl Environ Microbiol 57, pp. 3529-3534, 1991.

[9] Tsen, H.Y., Lin C.K. and Chi W.R. Development and use of 16S rRNA gene targeted PCR primers for the identification of Escherichia coli cells in water. J Appl Microbiol 85, pp. 554-560, 1998.

[10] Venkateswaran, K., Dohmoto, N. and Harayama, S. Cloning and nucleotide sequence of the gyrB gene of Vibrio haemolyticus and its application in detection of this pathogen in shrimp. Appl Environ Microbiol 64(2), pp. 681-687, 1998.

[11] Yamamoto, S. and Harayama, S. PCR amplification and direct sequencing of gyrB genes with universal primers and their application to the detection and taxonomic analysis of Pseudomonas putida strains. Appl Environ Microbiol 61(3), pp. 1104-1109, 1995.

[12] Mukhopadhyay, A. and Mukhopadhyay, U.K. Novel multiplex PCR approaches for the simultaneous detection of human pathogens: Escherichia coli 0157:H7 and Listeria monocytogenes. J Microbiol Methods 68, pp. 193-200, 2007.

[13] Fey, A., Eichler, S., Flavier, S., Christen, R., Höfle, M.G. and Guzmán, C.A. Establishment of a real-time PCR-based approach for accurate quantification of bacterial RNA targets in water, using Salmonella as a model organism. Appl Environ Microbiol 70(6), pp. 3618-3623, 2004.

[14] Guy, R.A., Payment, P., Krull, U.J. and Horgen, P.A. Real-time PCR for quantification of Giardia and Cryptosporidium in environmental water samples and sewage. Appl Environ Microbiol 69, pp. 5178-5185, 2003.

[15] Layton, A., McKay, L., Williams, D., Garrett, V., Gentry, R. and Sayler, G. Development of Bacteroides 16S rRNA gene TaqMan-based real-time PCR 
assays for estimation of total, human, and bovine fecal pollution in water. Appl Environ Microbiol 72(6), pp. 4214-4224, 2006.

[16] Kuske, C. R., S. M. Barns, and J. D. Busch. Diverse uncultivated bacterial groups from soils of the arid southwestern United States that are present in many geographic regions. Appl Environ Microbiol 63, pp. 3614-3621, 1997. 